University of Wyoming College of Law

Law Archive of Wyoming Scholarship

$11-28-2012$

\title{
Adapting to Climate Change on Western Public Lands: Addressing the Ecological Effects of Domestic, Wild, and Feral Ungulates
}

Dominick A. DellaSala

Unaffiliated Authors - Independent, author1938681@ssrn.com

Jonathan J. Rhodes

Planeto Azul Hydrology, author1753467@ssrn.com

James R. Karr

Mary H. O'Brien

Grand Canyon Trust, author1938683@ssrn.com

Thomas L. Fleischner

Prescott College - Environmental Studies, author1938686@ssrn.com

See next page for additional authors

Follow this and additional works at: https://scholarship.law.uwyo.edu/faculty_articles

\section{Recommended Citation}

DellaSala, Dominick A.; Rhodes, Jonathan J.; Karr, James R.; O'Brien, Mary H.; Fleischner, Thomas L.; Donahue, Debra L.; Beschta, Robert L.; and Williams, Cindy Deacon, "Adapting to Climate Change on Western Public Lands: Addressing the Ecological Effects of Domestic, Wild, and Feral Ungulates" (2012). Faculty Articles. 14.

https://scholarship.law.uwyo.edu/faculty_articles/14

This Article is brought to you for free and open access by the UW College of Law Faculty Scholarship at Law Archive of Wyoming Scholarship. It has been accepted for inclusion in Faculty Articles by an authorized administrator of Law Archive of Wyoming Scholarship. 


\section{Authors}

Dominick A. DellaSala, Jonathan J. Rhodes, James R. Karr, Mary H. O'Brien, Thomas L. Fleischner, Debra L. Donahue, Robert L. Beschta, and Cindy Deacon Williams 


\title{
Adapting to Climate Change on Western Public Lands: Addressing the Ecological Effects of Domestic, Wild, and Feral Ungulates
}

\author{
Robert L. Beschta - Debra L. Donahue - Dominick A. DellaSala • \\ Jonathan J. Rhodes · James R. Karr • Mary H. O'Brien • \\ Thomas L. Fleischner • Cindy Deacon Williams
}

Received: 27 January 2012/ Accepted: 13 September 2012

(C) Springer Science+Business Media New York 2012

\begin{abstract}
Climate change affects public land ecosystems and services throughout the American West and these effects are projected to intensify. Even if greenhouse gas emissions are reduced, adaptation strategies for public lands are needed to reduce anthropogenic stressors of terrestrial and aquatic ecosystems and to help native species and ecosystems survive in an altered environment. Historical and contemporary livestock production-the most widespread and long-running commercial use of public
\end{abstract}

R. L. Beschta $(\varangle)$

Department of Forest Ecosystems and Society, Oregon State University, Corvallis, OR 97331, USA

e-mail: robert.beschta@oregonstate.edu

\section{L. Donahue}

College of Law, University of Wyoming, Department 3035, 1000 East University Avenue, Laramie, WY 82071, USA

D. A. DellaSala

Geos Institute, 84 Fourth Street, Ashland, OR 97520, USA

J. J. Rhodes

Planeto Azul Hydrology, P.O. Box 15286, Portland, OR 97293,

USA

J. R. Karr

190 Cascadia Loop, Sequim, WA 98382, USA

M. H. O'Brien

Grand Canyon Trust, HC 64 Box 2604, Castle Valley, UT

84532, USA

\section{T. L. Fleischner}

Environmental Studies, Prescott College, 220 Grove Avenue,

Prescott, AZ 86301, USA

C. Deacon Williams

Environmental Consultants, 4393 Pioneer Road, Medford, OR 97501, USA lands - can alter vegetation, soils, hydrology, and wildlife species composition and abundances in ways that exacerbate the effects of climate change on these resources. Excess abundance of native ungulates (e.g., deer or elk) and feral horses and burros add to these impacts. Although many of these consequences have been studied for decades, the ongoing and impending effects of ungulates in a changing climate require new management strategies for limiting their threats to the long-term supply of ecosystem services on public lands. Removing or reducing livestock across large areas of public land would alleviate a widely recognized and long-term stressor and make these lands less susceptible to the effects of climate change. Where livestock use continues, or where significant densities of wild or feral ungulates occur, management should carefully document the ecological, social, and economic consequences (both costs and benefits) to better ensure management that minimizes ungulate impacts to plant and animal communities, soils, and water resources. Reestablishing apex predators in large, contiguous areas of public land may help mitigate any adverse ecological effects of wild ungulates.

Keywords Ungulates - Climate change - Ecosystems . Public lands · Biodiversity $\cdot$ Restoration

\section{Introduction}

During the 20th century, the average global surface temperature increased at a rate greater than in any of the previous nine centuries; future increases in the United States (US) are likely to exceed the global average (IPCC 2007a; Karl and others 2009). In the western US, where most public lands are found, climate change is predicted to 
intensify even if greenhouse gas emissions are reduced dramatically (IPCC 2007b). Climate-related changes can not only affect public-land ecosystems directly, but may exacerbate the aggregate effects of non-climatic stressors, such as habitat modification and pollution caused by logging, mining, grazing, roads, water diversions, and recreation (Root and others 2003; CEQ 2010; Barnosky and others 2012).

One effective means of ameliorating the effects of climate change on ecosystems is to reduce environmental stressors under management control, such as land and water uses (Julius and others 2008; Heller and Zavaleta 2009; Prato 2011). Public lands in the American West provide important opportunities to implement such a strategy for three reasons: (1) despite a history of degradation, public lands still offer the best available opportunities for ecosystem restoration (CWWR 1996; FS and BLM 1997; Karr 2004); (2) two-thirds of the runoff in the West originates on public lands (Coggins and others 2007); and (3) ecosystem protection and restoration are consistent with laws governing public lands. To be effective, restoration measures should address management practices that prevent public lands from providing the full array of ecosystem services and/or are likely to accentuate the effects of climate change (Hunter and others 2010). Although federal land managers have recently begun considering how to adapt to and mitigate potential climate-related impacts (e.g., GAO 2007; Furniss and others 2009; CEQ 2010; Peterson and others 2011), they have not addressed the combined effects of climate change and ungulates (hooved mammals) on ecosystems.

Climate change and ungulates, singly and in concert, influence ecosystems at the most fundamental levels by affecting soils and hydrologic processes. These effects, in turn, influence many other ecosystem components and processes-nutrient and energy cycles; reproduction, survival, and abundance of terrestrial and aquatic species; and community structure and composition. Moreover, by altering so many factors crucial to ecosystem functioning, the combined effects of a changing climate and ungulate use can affect biodiversity at scales ranging from species to ecosystems (FS 2007) and limit the capability of large areas to supply ecosystem services (Christensen and others 1996; MEA 2005b).

In this paper, we explore the likely ecological consequences of climate change and ungulate use, individually and in combination, on public lands in the American West. Three general categories of large herbivores are considered: livestock (largely cattle [Bos taurus] and sheep [Ovis aries]), native ungulates (deer [Odocoileus spp.] and elk [Cervus spp.]), and feral ungulates (horses [Equus cabal$l u s]$ and burros [E. asinus]). Based on this assessment, we propose first-order recommendations to decrease these consequences by reducing ungulate effects that can be directly managed.

\section{Climate Change in the Western US}

Anticipated changes in atmospheric carbon dioxide $\left(\mathrm{CO}_{2}\right)$, temperature, and precipitation (IPCC 2007a) are likely to have major repercussions for upland plant communities in western ecosystems (e.g., Backlund and others 2008), eventually affecting the distribution of major vegetation types. Deserts in the southwestern US, for example, will expand to the north and east, and in elevation (Karl and others 2009). Studies in southeastern Arizona have already attributed dramatic shifts in species composition and plant and animal populations to climate-driven changes (Brown and others 1997). Thus, climate-induced changes are already accelerating the ongoing loss of biodiversity in the American West (Thomas and others 2004).

Future decreases in soil moisture and vegetative cover due to elevated temperatures will reduce soil stability (Karl and others 2009). Wind erosion is likely to increase dramatically in some ecosystems such as the Colorado Plateau (Munson and others 2011) because biological soil crustsa complex mosaic of algae, lichens, mosses, microfungi, cyanobacteria, and other bacteria-may be less drought tolerant than many desert vascular plant species (Belnap and others 2006). Higher air temperatures may also lead to elevated surface-level concentrations of ozone (Karl and others 2009), which can reduce the capacity of vegetation to grow under elevated $\mathrm{CO}_{2}$ levels and sequester carbon (Karnosky and others 2003).

Air temperature increases and altered precipitation regimes will affect wildfire behavior and interact with insect outbreaks (Joyce and others 2009). In recent decades, climate change appears to have increased the length of the fire season and the area annually burned in some western forest types (Westerling and others 2006; ITF 2011). Climate induced increases in wildfire occurrence may aggravate the expansion of cheatgrass (Bromus tectorum), an exotic annual that has invaded millions of hectares of sagebrush (Artemisia spp.) steppe, a widespread yet threatened ecosystem. In turn, elevated wildfire occurrence facilitates the conversion of sagebrush and other native shrub-perennial grass communities to those dominated by alien grasses (D'Antonio and Vitousek 1992; Brooks 2008), resulting in habitat loss for imperiled greater sage-grouse (Centrocercus urophasianus) and other sagebrush-dependent species (Welch 2005). The US Fish and Wildlife Service (FWS 2010) recently concluded climate change effects can exacerbate many of the multiple threats to sagebrush habitats, including wildfire, invasive plants, and heavy ungulate use. In addition, the combined effects 
of increased air temperatures, more frequent fires, and elevated $\mathrm{CO}_{2}$ levels apparently provide some invasive species with a competitive advantage (Karl and others 2009).

By the mid-21st century, Bates and others (2008) indicate that warming in western mountains is very likely to cause large decreases in snowpack, earlier snowmelt, more winter rain events, increased peak winter flows and flooding, and reduced summer flows. Annual runoff is predicted to decrease by 10-30\% in mid-latitude western North America by 2050 (Milly and others 2005) and up to $40 \%$ in Arizona (Milly and others 2008; ITF 2011). Drought periods are expected to become more frequent and longer throughout the West (Bates and others 2008). Summertime decreases in streamflow (Luce and Holden 2009) and increased water temperatures already have been documented for some western rivers (Kaushal and others 2010; Isaak and others 2012).

Snowmelt supplies about $60-80 \%$ of the water in major western river basins (the Columbia, Missouri, and Colorado Rivers) and is the primary water supply for about 70 million people (Pederson and others 2011). Contemporary and future declines in snow accumulations and runoff (Mote and others 2005; Pederson and others 2011) are an important concern because current water supplies, particularly during low-flow periods, are already inadequate to satisfy demands over much of the western US (Piechota and others 2004; Bates and others 2008).

High water temperatures, acknowledged as one of the most prevalent water quality problems in the West, will likely be further elevated and may render one-third of the current coldwater fish habitat in the Pacific Northwest unsuitable by this century's end (Karl and others 2009). Resulting impacts on salmonids include increases in virulence of disease, loss of suitable habitat, and mortality as well as increased competition and predation by warmwater species (EPA 1999). Increased water temperatures and changes in snowmelt timing can also affect amphibians adversely (Field and others 2007). In sum, climate change will have increasingly significant effects on public-land terrestrial and aquatic ecosystems, including plant and animal communities, soils, hydrologic processes, and water quality.

\section{Ungulate Effects and Climate Change Synergies}

Climate change in the western US is expected to amplify "combinations of biotic and abiotic stresses that compromise the vigor of ecosystems-leading to increased extent and severity of disturbances" (Joyce and others 2008, p. 16). Of the various land management stressors affecting western public lands, ungulate use is the most widespread
(Fig. 1). Domestic livestock annually utilize over $70 \%$ of lands managed by the Bureau of Land Management (BLM) and US Forest Service (FS). Many public lands are also used by wild ungulates and/or feral horses and burros, which are at high densities in some areas. Because ungulate groups can have different effects, we discuss them individually.

\section{Livestock}

\section{History and Current Status}

Livestock were introduced to North America in the midsixteenth century, with a massive influx from the mid1800s through early 1900s (Worster 1992). The deleterious effects of livestock-including herbivory of both herbaceous and woody plants and trampling of vegetation, soils, and streambanks - prompted federal regulation of grazing on western national forests beginning in the 1890s (Fleischner 2010). Later, the 1934 Taylor Grazing Act was enacted "to stop injury to the public grazing lands by preventing overgrazing and soil deterioration" on lands subsequently administered by the BLM.

Total livestock use of federal lands in eleven contiguous western states today is nearly 9 million animal unit months (AUMs, where one AUM represents forage use by a cow and calf pair, one horse, or five sheep for one month) (Fig. 2a). Permitted livestock use occurs on nearly one million square kilometers of public land annually, including $560,000 \mathrm{~km}^{2}$ managed by the BLM, $370,000 \mathrm{~km}^{2}$ by the FS, $6,000 \mathrm{~km}^{2}$ by the National Park Service (NPS), and $3,000 \mathrm{~km}^{2}$ by the US Fish and Wildlife Service (FWS).

Livestock use affects a far greater proportion of BLM and FS lands than do roads, timber harvest, and wildfires combined (Fig. 3). Yet attempts to mitigate the pervasive effects of livestock have been minor compared with those aimed at reducing threats to ecosystem diversity and productivity that these other land uses pose. For example, much effort is often directed at preventing and controlling wildfires since they can cause significant property damage and social impacts. On an annual basis, however, wildfires affect a much smaller portion of public land than livestock grazing (Fig. 3) and they can also result in ecosystem benefits (Rhodes and Baker 2008; Swanson and others 2011).

The site-specific impacts of livestock use vary as a function of many factors (e.g., livestock species and density, periods of rest or non-use, local plant communities, soil conditions). Nevertheless, extensive reviews of published research generally indicate that livestock have had numerous and widespread negative effects to western ecosystems (Love 1959; Blackburn 1984; Fleischner 1994; Belsky and others 1999; Kauffman and Pyke 2001; Asner 
Fig. 1 Areas of public-lands livestock grazing managed by federal agencies in the western US (adapted from Salvo 2009)

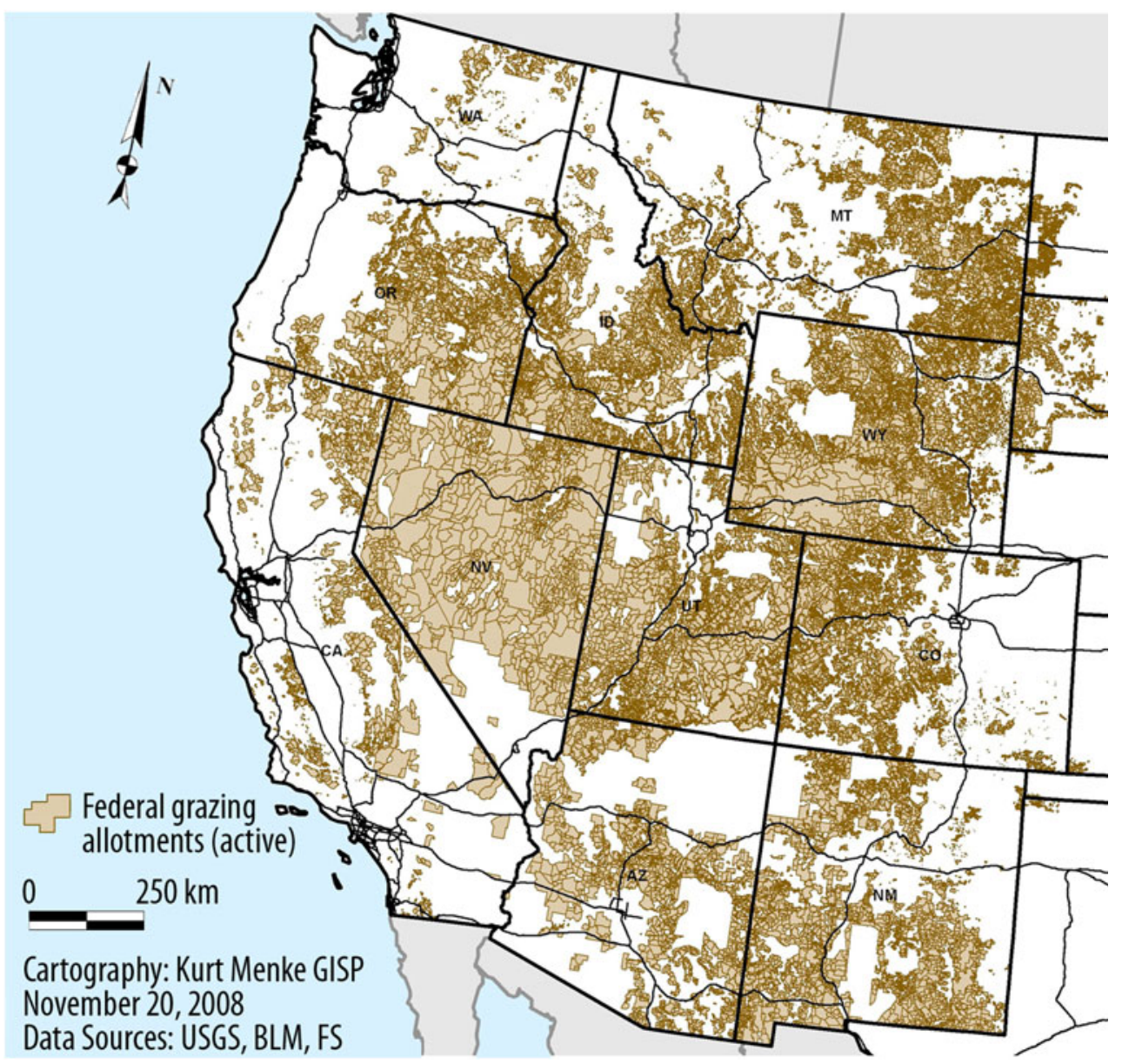

2009). Even absent desertification, light to moderate grazing intensities can promote woody species encroachment in semiarid and mesic environments (Asner and others 2004, p. 287). Nearly two decades ago, many public-land ecosystems, including native shrub steppe in Oregon and Washington, sagebrush steppe in the Intermountain West, and riparian plant communities, were considered threatened, endangered, or critically endangered (Noss and others 1995).

Simplified plant communities combine with loss of vegetation mosaics across landscapes to affect pollinators, birds, small mammals, amphibians, wild ungulates, and other native wildlife (Bock and others 1993; Fleischner 1994; Saab and others 1995; Ohmart 1996). Ohmart and Anderson (1986) suggested that livestock grazing may be the major factor negatively affecting wildlife in eleven western states. Such effects will compound the problems of adaptation of these ecosystems to the dynamics of climate change (Joyce and others 2008, 2009). Currently, the widespread and ongoing declines of many North American bird populations that use grassland and grass-shrub habitats affected by grazing are "on track to become a prominent wildlife conservation crisis of the 21 st century" (Brennan and Kuvlesky 2005, p. 1). 


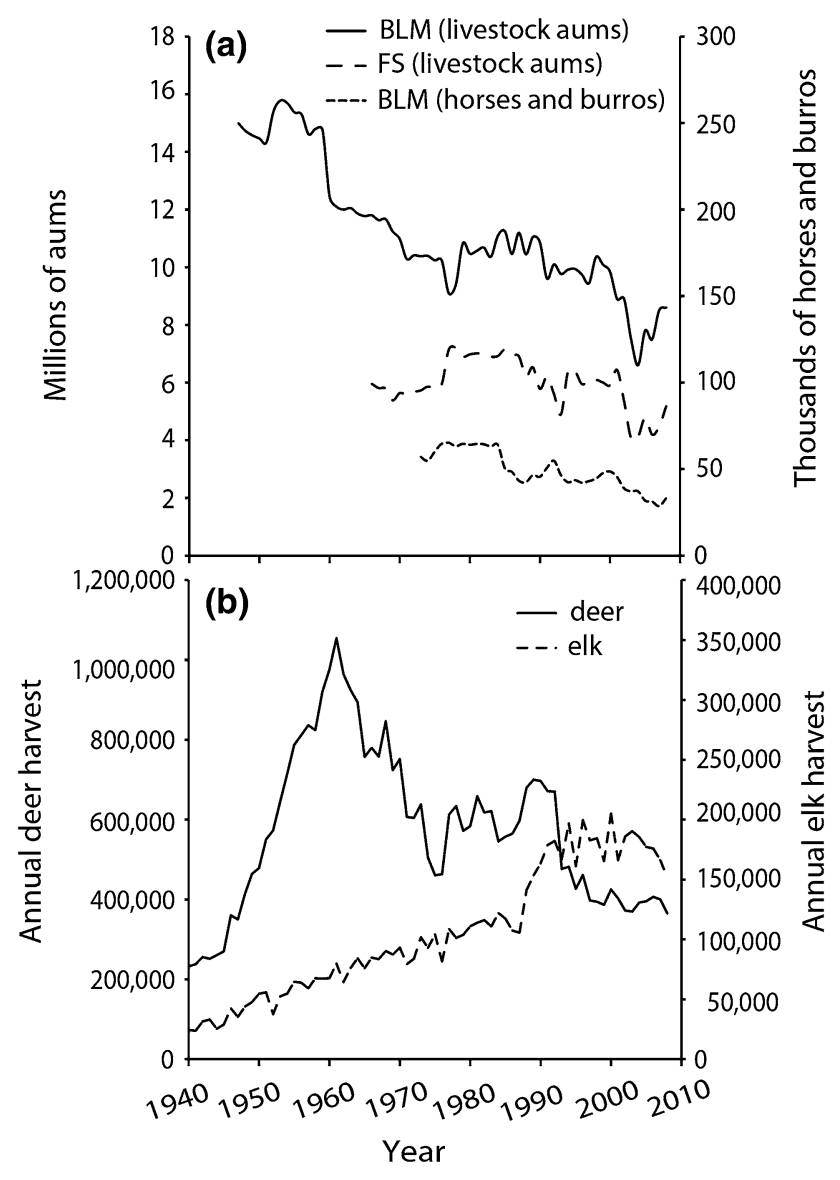

Fig. 2 a Bureau of Land Management (BLM) and US Forest Service (FS) grazing use in animal unit months (AUMs) and number of feral horses and burros on BLM lands, and $\mathbf{b}$ annual harvest of deer and elk by hunters, for eleven western states. Data sources a BLM grazing and number of horses and burros reported annually in Public Land Statistics; FS grazing reported annually in Grazing Statistical Summary; b deer and elk harvest records from individual state wildlife management agencies

\section{Soils and Biological Soil Crusts}

Livestock grazing and trampling can damage or eliminate biological soil crusts characteristic of many arid and semiarid regions (Belnap and Lange 2003; Asner and others 2004). These complex crusts are important for fertility, soil stability, and hydrology (Belnap and Lange 2003). In arid and semiarid regions they provide the major barrier against wind erosion and dust emission (Munson and others 2011). Currently, the majority of dust emissions in North America originate in the Great Basin, Colorado Plateau, and Mojave and Sonoran Deserts, areas that are predominantly public lands and have been grazed for nearly 150 years. Elevated sedimentation in western alpine lakes over this period has also been linked to increased aeolian deposition stemming from land uses, particularly those associated with livestock grazing (Neff and others 2008).

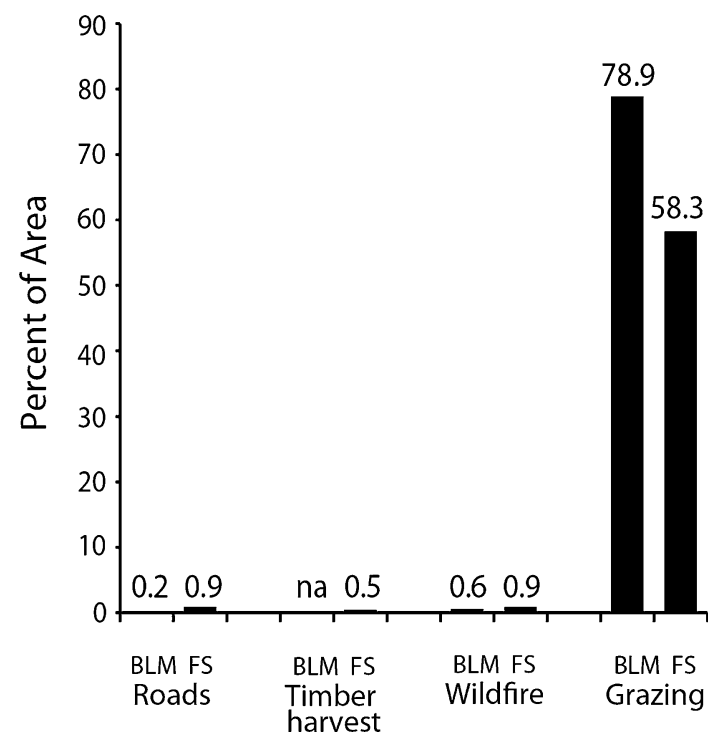

Fig. 3 Percent of Bureau of Land Management (BLM) and US Forest Service (FS) lands in eleven western states that are occupied by roads or are affected annually by timber harvest, wildfire, and grazing. Data sources Roads, BLM (2009) and FS, Washington Office; Timber harvest (2003-09), FS, Washington Office; Wildfire (2003-09), National Interagency Fire Center, Missoula, Montana; Grazing, BLM (2009) and GAO (2005). "na" = not available

If livestock use on public lands continues at current levels, its interaction with anticipated changes in climate will likely worsen soil erosion, dust generation, and stream pollution. Soils whose moisture retention capacity has been reduced will undergo further drying by warming temperatures and/or drought and become even more susceptible to wind erosion (Sankey and others 2009). Increased aeolian deposition on snowpack will hasten runoff, accentuating climate-induced hydrological changes on many public lands (Neff and others 2008). Warmer temperatures will likely trigger increased fire occurrence, causing further reductions in cover and composition of biological soil crusts (Belnap and others 2006), as well as vascular plants (Munson and others 2011). In some forest types, where livestock grazing has contributed to altered fire regimes and forest structure (Belsky and Blumenthal 1997; Fleischner 2010), climate change will likely worsen these effects.

\section{Water and Riparian Resources}

Although riparian areas occupy only 1-2\% of the West's diverse landscapes, they are highly productive and ecologically valuable due to the vital terrestrial habitats they provide and their importance to aquatic ecosystems (Kauffman and others 2001; NRC 2002; Fleischner 2010). Healthy riparian plant communities provide important corridors for the movement of plant and animal species 
(Peterson and others 2011). Such communities are also crucial for maintaining water quality, food webs, and channel morphology vital to high-quality habitats for fish and other aquatic organisms in the face of climate change. For example, well-vegetated streambanks not only shade streams but also help to maintain relatively narrow and stable channels, attributes essential for preventing increased stream temperatures that negatively affect salmonids and other aquatic organisms (Sedell and Beschta 1991; Kondolf and others 1996; Beschta 1997); maintaining cool stream temperatures is becoming even more important with climate change (Isaak and others 2012). Riparian vegetation is also crucial for providing seasonal fluxes of organic matter and invertebrates to streams (Baxter and others 2005). Nevertheless, in 1994 the BLM and FS reported that western riparian areas were in their worst condition in history, and livestock use-typically concentrated in these areas-was the chief cause (BLM and FS 1994).

Livestock grazing has numerous consequences for hydrologic processes and water resources. Livestock can have profound effects on soils, including their productivity, infiltration, and water storage, and these properties drive many other ecosystem changes. Soil compaction from livestock has been identified as an extensive problem on public lands (CWWR 1996; FS and BLM 1997). Such compaction is inevitable because the hoof of a $450-\mathrm{kg}$ cow exerts more than five times the pressure of heavy earthmoving machinery (Cowley 2002). Soil compaction significantly reduces infiltration rates and the ability of soils to store water, both of which affect runoff processes (Branson and others 1981; Blackburn 1984). Compaction of wet meadow soils by livestock can significantly decrease soil water storage (Kauffman and others 2004), thus contributing to reduced summer base flows. Concomitantly, decreases in infiltration and soil water storage of compacted soils during periods of high-intensity rainfall contribute to increased surface runoff and soil erosion (Branson and others 1981). These fundamental alterations in hydrologic processes from livestock use are likely to be exacerbated by climate change.

The combined effects of elevated soil loss and compaction caused by grazing reduce soil productivity, further compromising the capability of grazed areas to support native plant communities (CWWR 1996; FS and BLM 1997). Erosion triggered by livestock use continues to represent a major source of sediment, nutrients, and pathogens in western streams (WSWC 1989; EPA 2009). Conversely, the absence of grazing results in increased litter accumulation, which can reduce runoff and erosion and retard desertification (Asner and others 2004).

Historical and contemporary effects of livestock grazing and trampling along stream channels can destabilize streambanks, thus contributing to widened and/or incised channels (NRC 2002). Accelerated streambank erosion and channel incision are pervasive on western public lands used by livestock (Fig. 4). Stream incision contributes to desiccation of floodplains and wet meadows, loss of floodwater detention storage, and reductions in baseflow (Ponce and Lindquist 1990; Trimble and Mendel 1995). Grazing and trampling of riparian plant communities also contribute to elevated water temperatures-directly, by reducing stream shading and, indirectly, by damaging streambanks and increasing channel widths (NRC 2002). Livestock use of riparian plant communities can also decrease the availability of food and construction materials for keystone species such as beaver (Castor canadensis).

Livestock effects and climate change can interact in various ways with often negative consequences for aquatic species and their habitats. In the eleven ecoregions encompassing western public lands (excluding coastal regions and Alaska), about 175 taxa of freshwater fish are considered imperiled (threatened, endangered, vulnerable, possibly extinct, or extinct) due to habitat-related causes (Jelks and others 2008, p. 377; GS and AFS 2011). Increased sedimentation and warmer stream temperatures associated with livestock grazing have contributed significantly to the long-term decline in abundance and distribution and loss of native salmonids, which are imperiled throughout the West (Rhodes and others 1994; Jelks and others 2008).

Water developments and diversions for livestock are common on public lands (Connelly and others 2004). For example, approximately $3,700 \mathrm{~km}$ of pipeline and 2,300 water developments were installed on just $17 \%$ of the BLM's land base from 1961 to 1999 in support of livestock operations (Rich and others 2005). Such developments can reduce streamflows thus contributing to warmer stream temperatures and reduced fish habitat, both serious problems for native coldwater fish (Platts 1991; Richter and others 1997). Reduced flows and higher temperatures are also risk factors for many terrestrial and aquatic vertebrates (Wilcove and others 1998). Water developments can also create mosquito (e.g., Culex tarsalis) breeding habitat, potentially facilitating the spread of West Nile virus, which poses a significant threat to sage grouse (FWS 2010). Such developments also tend to concentrate livestock and other ungulate use, thus locally intensifying grazing and trampling impacts.

\section{Greenhouse Gas Emissions and Energy Balances}

Livestock production impacts energy and carbon cycles and globally contributes an estimated $18 \%$ to the total anthropogenic greenhouse gas (GHG) emissions (Steinfeld and others 2006). How public-land livestock contribute to 

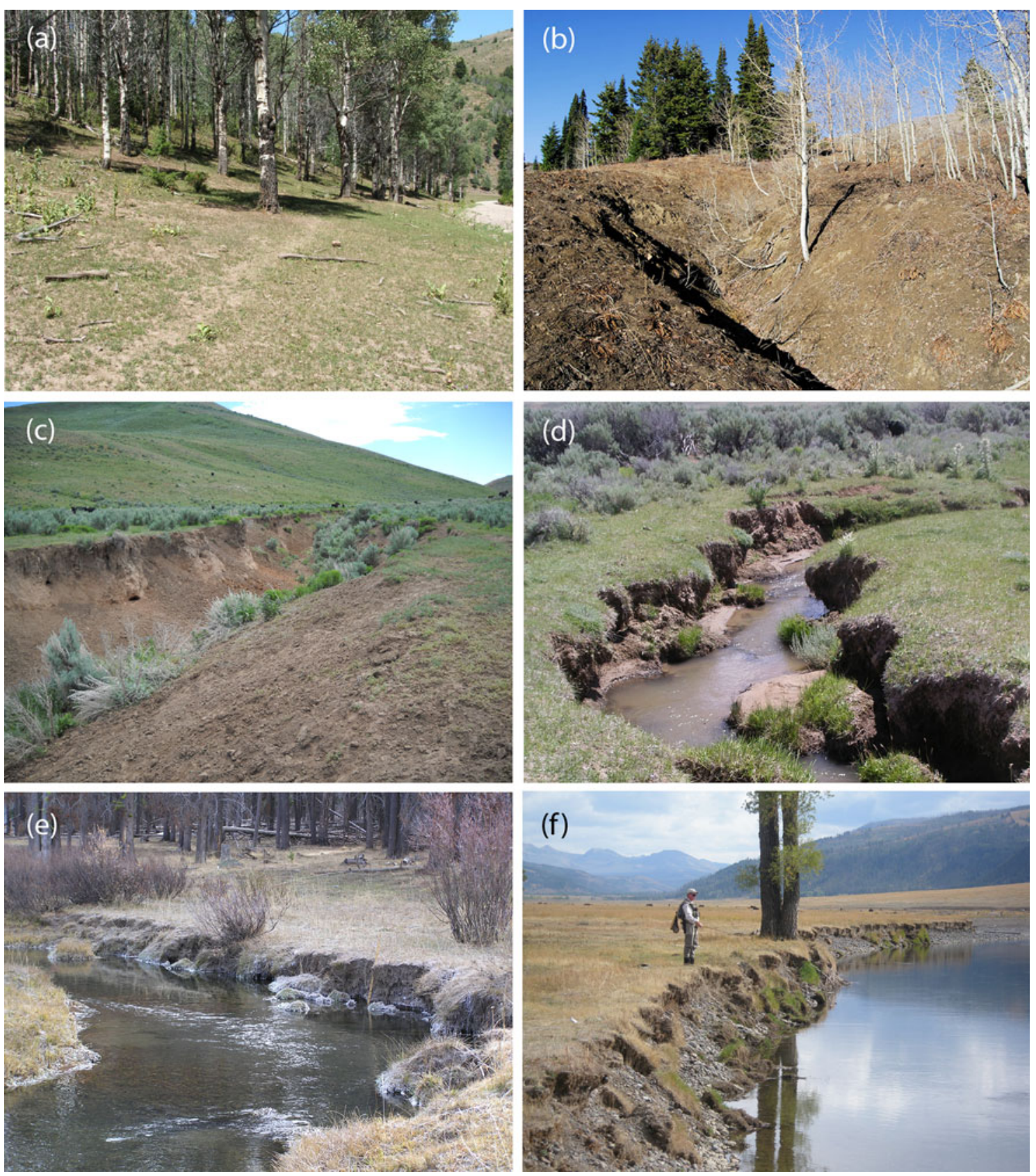

Fig. 4 Examples of long-term grazing impacts from livestock, unless otherwise noted: a bare soil, loss of understory vegetation, and lack of aspen recruitment (i.e., growth of seedlings/sprouts into tall saplings and trees) (Bureau of Land Management, Idaho), b bare soil, lack of ground cover, lack of aspen recruitment and channel incision (US Forest Service, Idaho), c conversion of a perennial stream to an intermittent stream due to grazing of riparian vegetation and subsequent channel incision; channel continues to erode during runoff events (Bureau of Land Management, Utah), d incised and

these effects has received little study. Nevertheless, livestock grazing and trampling can reduce the capacity of rangeland vegetation and soils to sequester carbon and contribute to the loss of above- and below-ground carbon pools (e.g., Lal 2001b; Bowker and others 2012).

widening stream due to loss of streamside vegetation and bank collapse from trampling (Bureau of Land Management, Wyoming), e incised and widening stream due to loss of streamside vegetation and bank collapse from trampling (US Forest Service, Oregon), and f actively eroding streambank from the loss of streamside vegetation due to several decades of excessive herbivory by elk and, more recently, bison (National Park Service, Wyoming). Photographs a J Carter, b G Wuerthner, c and d J Carter, e and f R Beschta

Lal (2001a) indicated that heavy grazing over the longterm may have adverse impacts on soil organic carbon content, especially for soils of low inherent fertility. Although Gill (2007) found that grazing over 100 years or longer in subalpine areas on the Wasatch Plateau in central 
Utah had no significant impacts on total soil carbon, results of the study suggest that "if temperatures warm and summer precipitation increases as is anticipated, [soils in grazed areas] may become net sources of $\mathrm{CO}_{2}$ to the atmosphere" (Gill 2007, p. 88). Furthermore, limited soil aeration in soils compacted by livestock can stimulate production of methane, and emissions of nitrous oxide under shrub canopies may be twice the levels in nearby grasslands (Asner and others 2004). Both of these are potent GHGs.

Reduced plant and litter cover from livestock use can increase the albedo (reflectance) of land surfaces, thereby altering radiation energy balances (Balling and others 1998). In addition, widespread airborne dust generated by livestock is likely to increase with the drying effects of climate change. Air-borne dust influences atmospheric radiation balances as well as accelerating melt rates when deposited on seasonal snowpacks and glaciers (Neff and others 2008).

\section{Other Livestock Effects}

Livestock urine and feces add nitrogen to soils, which may favor nonnative species (BLM 2005), and can lead to loss of both organic and inorganic nitrogen in increased runoff (Asner and others 2004). Organic nitrogen is also lost via increased trace-gas flux and vegetation removal by grazers (Asner and others 2004). Reduced soil nitrogen is problematic in western landscapes because nitrogen is an important limiting nutrient in most arid-land soils (Fleischner 2010).

Managing livestock on public lands also involves extensive fence systems. Between 1962 and 1997, over $51,000 \mathrm{~km}$ of fence were constructed on BLM lands with resident sage-grouse populations (FWS 2010). Such fences can significantly impact this wildlife species. For example, 146 sage-grouse died in less than three years from collisions with fences along a 7.6-km BLM range fence in Wyoming (FWS 2010). Fences can also restrict the movements of wild ungulates and increase the risk of injury and death by entanglement or impalement (Harrington and Conover 2006; FWS 2010). Fences and roads for livestock access can fragment and isolate segments of natural ecological mosaics thus influencing the capability of wildlife to adapt to a changing climate.

Some have posited that managed cattle grazing might play a role in maintaining ecosystem structure in shortgrass steppe ecosystems of the US, if it can mimic grazing by native bison (Bison bison) (Milchunas and others 1998). But most public lands lie to the west of the Great Plains, where bison distribution and effects were limited or nonexistent; livestock use (particularly cattle) on these lands exert disturbances without evolutionary parallel (Milchunas and Lauenroth 1993; MEA 2005a).
Feral Horses and Burros

Feral horses and burros occupy large areas of public land in the western US. For example, feral horses are found in ten western states and feral burros occur in five of these states, largely in the Mojave and Sonoran Deserts and the Great Basin (Abella 2008; FWS 2010). About half of these horses and burros are in Nevada (Coggins and others 2007), of which $90 \%$ are on BLM lands. Horse numbers peaked at perhaps two million in the early 1900s, but had plummeted to about 17,000 by 1971 , when protective legislation (Wild, Free-Ranging Horses and Burros Act [WFRHBA]) was passed (Coggins and others 2007). Protection resulted in increased populations and today some 40,000 feral horses and burros utilize $\sim 130,000 \mathrm{~km}^{2}$ of BLM and FS lands (DOI-OIG 2010; Gorte and others 2010). Currently, feral horse numbers are doubling every four years (DOI-OIG 2010); burro populations can also increase rapidly (Abella 2008). Unlike wild ungulates, feral equines cannot be hunted and, unlike livestock, they are not regulated by permit. Nor are their numbers controlled effectively by existing predators. Accordingly, the BLM periodically removes animals from herd areas; the NPS also has undertaken burro control efforts (Abella 2008).

In sage grouse habitat, high numbers of feral horses reduce vegetative cover and plant diversity, fragment shrub canopies, alter soil characteristics, and increase the abundance of invasive species, thus reducing the quality and quantity of habitat (Beever and others 2003; FWS 2010). Horses can crop plants close to the ground, impeding the recovery of affected vegetation. Feral burros also have had a substantial impact on Sonoran Desert vegetation, reducing the density and canopy cover of nearly all species (Hanley and Brady 1977). Although burro impacts in the Mojave Desert may not be as clear, perennial grasses and other preferred forage species likely require protection from grazing in burro-inhabited areas if revegetation efforts are to be successful (Abella 2008).

\section{Wild Ungulates}

Extensive harvesting of wild (native) ungulates, such as elk and deer, and the decimation of large predator populations (e.g., gray wolf [Canis lupus], grizzly bear [Ursus arctos], and cougar [Puma concolor]) was common during early EuroAmerican settlement of the western US. With continued predator control in the early 1900s and increased protection of game species by state agencies, however, wild ungulate populations began to increase in many areas. Although only 70,000 elk inhabited the western US in the early 1900s (Graves and Nelson 1919), annual harvest data indicate that elk abundance has increased greatly since the about the 1940s (Fig. 2b), due in part to the loss of apex 
predators (Allen 1974; Mackie and others 1998). Today, approximately one million elk (Karnopp 2008) and unknown numbers of deer inhabit the western US where they often share public lands with livestock.

Because wild ungulates typically occur more diffusely across a landscape than livestock, their presence might be expected to cause minimal long-term impacts to vegetation. Where wild ungulates are concentrated, however, their browsing can have substantial impacts. For example, sagebrush vigor can be reduced resulting in decreased cover or mortality (FWS 2010). Heavy browsing effects have also been documented on other palatable woody shrubs, as well as deciduous trees such as aspen (Populus tremuloides), cottonwood (Populus spp.), and maple (Acer sp.) (Beschta and Ripple 2009).

Predator control practices that intensified following the introduction of domestic livestock in the western US resulted in the extirpation of apex predators or reduced their numbers below ecologically effective densities (Soulé and others 2003, 2005), causing important cascading effects in western ecosystems (Beschta and Ripple 2009). Following removal of large predators on the Kaibab Plateau in the early 20th century, for example, an irruption of mule deer (O. hemionus) led to extensive over-browsing of aspen, other deciduous woody plants, and conifers; deterioration of range conditions; and the eventual crash of the deer population (Binkley and others 2006). In the absence of apex predators, wild ungulate populations can significantly limit recruitment of woody browse species, contribute to shifts in abundance and distribution of many wildlife species (Berger and others 2001; Weisberg and Coughenour 2003), and can alter streambanks and riparian communities that strongly influence channel morphology and aquatic conditions (Beschta and Ripple 2012). Numerous studies support the conclusion that disruptions of trophic cascades due to the decline of apex predators constitute a threat to biodiversity for which the best management solution is likely the restoration of effective predation regimes (Estes and others 2011).

\section{Ungulate Herbivory and Disturbance Regimes}

Across the western US, ecosystems evolved with and were sustained by local and regional disturbances, such as fluctuating weather patterns, fire, disease, insect infestation, herbivory by wild ungulates and other organisms, and hunting by apex predators. Chronic disturbances with relatively transient effects, such as frequent, low-severity fires and seasonal moisture regime fluctuations, helped maintain native plant community composition and structure. Relatively abrupt, or acute, natural disturbances, such as insect outbreaks or severe fires were also important for the maintenance of ecosystems and native species diversity (Beschta and others 2004; Swanson and others 2011). Livestock use and/or an overabundance of feral or wild ungulates can, however, greatly alter ecosystem response to disturbance and can degrade affected systems. For example, high levels of herbivory over a period of years, by either domestic or wild ungulates, can effectively prevent aspen sprouts from growing into tall saplings or trees as well as reduce the diversity of understory species (Shepperd and others 2001; Dwire and others 2007; Beschta and Ripple 2009).

Natural floods provide another illustration of how ungulates can alter the ecological role of disturbances. High flows are normally important for maintaining riparian plant communities through the deposition of nutrients, organic matter, and sediment on streambanks and floodplains, and for enhancing habitat diversity of aquatic and riparian ecosystems (CWWR 1996). Ungulate effects on the structure and composition of riparian plant communities (e.g., Platts 1991; Chadde and Kay 1996), however, can drastically alter the outcome of these hydrologic disturbances by diminishing streambank stability and severing linkages between high flows and the maintenance of streamside plant communities. As a result, accelerated erosion of streambanks and floodplains, channel incision, and the occurrence of high instream sediment loads may become increasingly common during periods of high flows (Trimble and Mendel 1995). Similar effects have been found in systems where large predators have been displaced or extirpated (Beschta and Ripple 2012). In general, high levels of ungulate use can essentially uncouple typical ecosystem responses to chronic or acute disturbances, thus greatly limiting the capacity of these systems to provide a full array of ecosystem services during a changing climate.

The combined effects of ungulates (domestic, wild, and feral) and a changing climate present a pervasive set of stressors on public lands, which are significantly different from those encountered during the evolutionary history of the region's native species. The intersection of these stressors is setting the stage for fundamental and unprecedented changes to forest, arid, and semi-arid landscapes in the western US (Table 1) and increasing the likelihood of alternative states. Thus, public-land management needs to focus on restoring and maintaining structure, function, and integrity of ecosystems to improve their resilience to climate change (Rieman and Isaak 2010).

\section{Federal Law and Policy}

Federal laws guide the use and management of public-land resources. Some laws are specific to a given agency (e.g., the BLM's Taylor Grazing Act of 1934 and the FS's 
Table 1 Generalized climate change effects, heavy ungulate use effects, and their combined effects as stressors to terrestrial and aquatic ecosystems in the western United States

\begin{tabular}{|c|c|c|}
\hline Climate change effects & Ungulate use effects & Combined effects \\
\hline $\begin{array}{l}\text { Increased drought frequency and } \\
\text { duration }\end{array}$ & $\begin{array}{l}\text { Altered upland plant and animal } \\
\text { communities }\end{array}$ & $\begin{array}{l}\text { Reduced habitat and food-web support; loss of mesic and } \\
\text { hydric plants, reduced biodiversity }\end{array}$ \\
\hline $\begin{array}{l}\text { Increased air temperatures, decreased } \\
\text { snowpack accumulation, earlier } \\
\text { snowmelt }\end{array}$ & $\begin{array}{l}\text { Compacted soils, decreased infiltration, } \\
\text { increased surface runoff }\end{array}$ & $\begin{array}{l}\text { Reduced soil moisture for plants, reduced productivity, } \\
\text { reductions in summer low flows, degraded aquatic } \\
\text { habitat }\end{array}$ \\
\hline $\begin{array}{l}\text { Increased variability in timing and } \\
\text { magnitude of precipitation events }\end{array}$ & $\begin{array}{l}\text { Decreased biotic crusts and litter cover, } \\
\text { increased surface erosion }\end{array}$ & $\begin{array}{l}\text { Accelerated soil and nutrient loss, increased } \\
\text { sedimentation }\end{array}$ \\
\hline Warmer and drier in the summer & $\begin{array}{l}\text { Reduced riparian vegetation, loss of } \\
\text { shade, increased stream width }\end{array}$ & $\begin{array}{l}\text { Increased stream temperatures, increased stress on cold- } \\
\text { water fish and aquatic organisms }\end{array}$ \\
\hline Increased variability in runoff & $\begin{array}{l}\text { Reduced root strength of riparian plants, } \\
\text { trampled streambanks, streambank } \\
\text { erosion }\end{array}$ & $\begin{array}{l}\text { Accelerated streambank erosion and increased } \\
\text { sedimentation, degraded water quality and aquatic } \\
\text { habitats }\end{array}$ \\
\hline Increased variability in runoff & Incised stream channels & $\begin{array}{l}\text { Degraded aquatic habitats, hydrologically disconnected } \\
\text { floodplains, reduced low flows }\end{array}$ \\
\hline
\end{tabular}

National Forest Management Act [NFMA] of 1976), whereas others cross agency boundaries (e.g., Endangered Species Act [ESA] of 1973; Clean Water Act [CWA] of 1972). A common mission of federal land management agencies is "to sustain the health, diversity, and productivity of public lands" (GAO 2007, p. 12). Further, each of these agencies has ample authority and responsibility to adjust management to respond to climate change (GAO 2007) and other stressors.

The FS and BLM are directed to maintain and improve the condition of the public rangelands so that they become as productive as feasible for all rangeland values. As defined, "range condition" encompasses factors such as soil quality, forage values, wildlife habitat, watershed and plant communities, and the present state of vegetation of a range site in relation to the potential plant community for that site (Public Rangelands Improvement Act of 1978). BLM lands and national forests must be managed for sustained yield of a wide array of multiple uses, values, and ecosystem services, including wildlife and fish, watershed, recreation, timber, and range. Relevant statutes call for management that meets societal needs, without impairing the productivity of the land or the quality of the environment, and which considers the "relative values" of the various resources, not necessarily the combination of uses that will give the greatest economic return or the greatest unit output (Multiple-Use Sustained-Yield Act of 1960; Federal Land Policy and Management Act of 1976 [FLPMA]).

FLPMA directs the BLM to "take any action necessary to prevent unnecessary or undue degradation" of the public lands. Under NFMA, FS management must provide for diversity of plant and animal communities based on the suitability and capability of the specific land area. FLMPA also authorizes both agencies to "cancel, suspend, or modify" grazing permits and to determine that "grazing uses should be discontinued (either temporarily or permanently) on certain lands." FLPMA explicitly recognizes the BLM's authority (with congressional oversight) to "totally eliminate" grazing from large areas $\left(>405 \mathrm{~km}^{2}\right)$ of public lands. These authorities are reinforced by law providing that grazing permits are not property rights (Public Lands Council v. Babbitt 2000).

While federal agencies have primary authority to manage federal public lands and thus wildlife habitats on these lands, states retain primary management authority over resident wildlife, unless preempted, as by the WFRHBA or ESA (Kleppe v. New Mexico 1976). Under WFRHBA, wild, free-roaming horses and burros (i.e., feral) by law have been declared "wildlife" and an integral part of the natural system of the public lands where they are to be managed in a manner that is designed to achieve and maintain a thriving natural ecological balance.

\section{Restoring Ungulate-Altered Ecosystems}

Because livestock use is so widespread on public lands in the American West, management actions directed at ecological restoration (e.g., livestock removal, substantial reductions in numbers or length of season, extended or regular periods of rest) need to be accomplished at landscape scales. Such approaches, often referred to as passive restoration, are generally the most ecologically effective and economically efficient for recovering altered ecosystems because they address the root causes of degradation and allow natural recovery processes to operate (Kauffman and others 1997; Rieman and Isaak 2010). Furthermore, reducing the impact of current stressors is a "no regrets" adaptation strategy that could be taken now to help enhance 

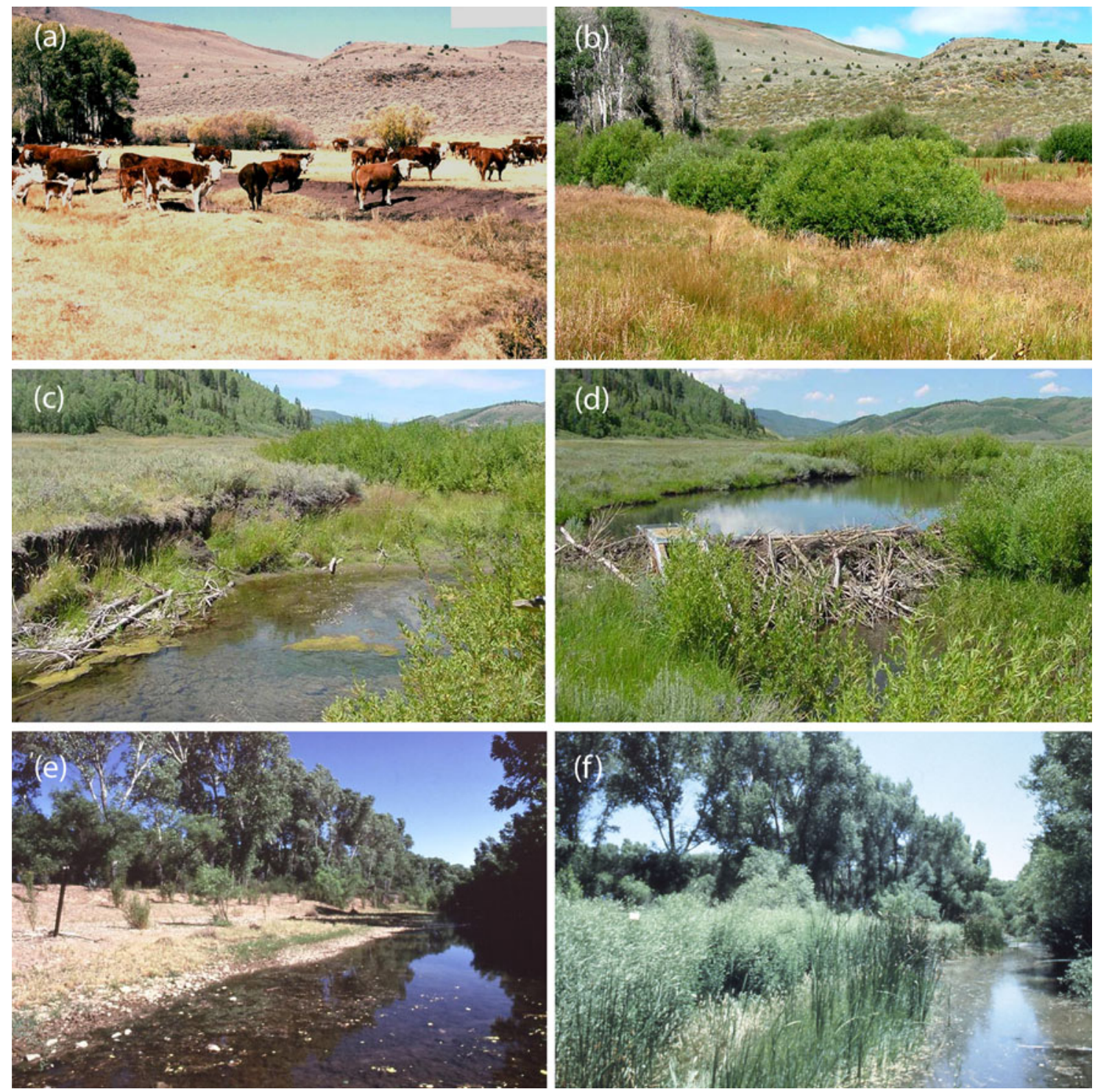

Fig. 5 Examples of riparian and stream recovery in the western United States after the removal of livestock grazing: Hart Mountain National Antelope Refuge, Oregon, in a October 1989 and b September 2010 after 18 years of livestock removal; Strawberry River, Utah, in c August 2002 after 13 years of livestock removal and d July 2003 illustrating improved streambank protection and riparian productivity as beaver reoccupy this river system; and San Pedro River, Arizona in e June 1987 and f June 1991 after 4 years of livestock removal. Photographs a Fish and Wildlife Service, Hart Mountain National Antelope Refuge, $\mathbf{b}$ J Rhodes, $\mathbf{c}$ and $\mathbf{d}$ US Forest Service, Uintah National Forest, $\mathbf{e}$ and $\mathbf{f}$ Bureau of Land Management, San Pedro Riparian National Conservation Area

ecosystem resilience to climate change (Joyce and others 2008). This strategy is especially relevant to western ecosystems because removing or significantly reducing the cause of degradation (e.g., excessive ungulate use) is likely to be considerably more effective over the long term, in both costs and approach, than active treatments aimed at specific ecosystem components (e.g., controlling invasive plants) (BLM 2005). Furthermore, the possibility that passive restoration measures may not accomplish all ecological goals is an insufficient reason for not removing or reducing stressors at landscape scales.
For many areas of the American West, particularly riparian areas and other areas of high biodiversity, significantly reducing or eliminating ungulate stressors should, over time, result in the recovery of self-sustaining and ecologically robust ecosystems (Kauffman and others 1997; Floyd and others 2003; Allington and Valone 2010; Fig. 5). Indeed, various studies and reviews have concluded that the most effective way to restore riparian areas and aquatic systems is to exclude livestock either temporarily (with subsequent changed management) or long-term (e.g., Platts 1991;BLM and FS 1994; Dobkin and others 
1998; NRC 2002; Seavy and others 2009: Fleischner 2010). Recovering channel form and riparian soils and vegetation by reducing ungulate impacts is also a viable management tool for increasing summer baseflows (Ponce and Lindquist 1990; Rhodes and others 1994).

In severely degraded areas, initiating recovery may require active measures in addition to the removal/reduction of stressors. For example, where native seed banks have been depleted, reestablishing missing species may require planting seeds or propagules from adjacent areas or refugia (e.g., Welch 2005). While active restoration approaches in herbivory-degraded landscapes may have some utility, such projects are often small in scope, expensive, and unlikely to be self-sustaining; some can cause unanticipated negative effects (Kauffman and others 1997). Furthermore, if ungulate grazing effects continue, any benefits from active restoration are likely to be transient and limited. Therefore, addressing the underlying causes of degradation should be the first priority for effectively restoring altered public-land ecosystems.

The ecological effectiveness and low cost of wide-scale reduction in ungulate use for restoring public-land ecosystems, coupled with the scarcity of restoration resources, provide a forceful case for minimizing ungulate impacts. Other conservation measures are unlikely to make as great a contribution to ameliorating landscape-scale effects from climate change or to do so at such a low fiscal cost. As Isaak and others $(2012$, p. 514) noted with regard to the impacts of climate change on widely-imperiled salmonids: "...conservation projects are likely to greatly exceed available resources, so strategic prioritization schemes are essential."

Although restoration of desertified lands was once thought unlikely, recovery in the form of significant increases in perennial grass cover has recently been reported at several such sites around the world where livestock have been absent for more than 20 years (Floyd and others 2003; Allington and Valone 2010; Peters and others 2011). At a desertified site in Arizona that had been ungrazed for 39 years, infiltration rates were significantly (24\%) higher (compared to grazed areas) and nutrient levels were elevated in the bare ground, inter-shrub areas (Allington and Valone 2010). The change in vegetative structure also affected other taxa (e.g., increased small mammal diversity) where grazing had been excluded (Valone and others 2002). The notion that regime shifts caused by grazing are irreversible (e.g., Bestelmeyer and others 2004) may be due to the relative paucity of largescale, ungulate-degraded systems where grazing has been halted for sufficiently long periods for recovery to occur.

Removing domestic livestock from large areas of public lands, or otherwise significantly reducing their impacts, is consistent with six of the seven approaches recommended for ecosystem adaptation to climate change (Julius and others 2008, pp. 1-3). Specifically, removing livestock would (1) protect key ecosystem features (e.g., soil properties, riparian areas); (2) reduce anthropogenic stressors; (3) ensure representation (i.e., protect a variety of forms of a species or ecosystem); (4) ensure replication (i.e., protect more than one example of each ecosystem or population); (5) help restore ecosystems; and (6) protect refugia (i.e., areas that can serve as sources of "seed" for recovery or as destinations for climate-sensitive migrants). Although improved livestock management practices are being adopted on some public lands, such efforts have not been widely implemented. Public land managers have rarely used their authority to implement landscape-scale rest from livestock use, lowered frequency of use, or multi-stakeholder planning for innovative grazing systems to reduce impacts.

While our findings are largely focused on adaptation strategies for western landscapes, reducing ungulate impacts and restoring degraded plant and soil systems may also assist in mitigating any ongoing or future changes in regional energy and carbon cycles that contribute to global climate change. Simply removing livestock can increase soil carbon sequestration since grasslands with the greatest potential for increasing soil carbon storage are those that have been depleted in the past by poor management $(\mathrm{Wu}$ and others 2008, citing Jones and Donnelly 2004). Riparian area restoration can also enhance carbon sequestration (Flynn and others 2009).

\section{Socioeconomic Considerations}

A comprehensive assessment of the socioeconomic effects of changes in ungulate management on public lands is beyond the scope of this paper. However, herein we identify a few of the general costs and benefits associated with implementing our recommendations (see next section), particularly with regard to domestic livestock grazing. The socioeconomic effects of altering ungulate management on public lands will ultimately depend on the type, magnitude, and location of changes undertaken by federal and state agencies.

Ranching is a contemporary and historically significant aspect of the rural West's social fabric. Yet, ranchers' stated preferences in response to grazing policy changes are as diverse as the ranchers themselves, and include intensifying, extensifying, diversifying, or selling their operations (Genter and Tanaka 2002). Surveys indicate that most ranchers are motivated more by amenity and lifestyle attributes than by profits (Torell and others 2001, Genter and Tanaka 2002). Indeed, economic returns from ranching are lower than any other investments with similar risk 
(Torrell and others 2001) and public-land grazing's contributions to income and jobs in the West are relatively small fractions of the region's totals (BLM and FS 1994; Power 1996).

If livestock grazing on public lands were discontinued or curtailed significantly, some operations would see reduced incomes and ranch values, some rural communities would experience negative economic impacts, and the social fabric of those communities could be altered (Genter and Tanaka 2002). But for most rural economies, and the West in general, the economic impacts of managing public lands to emphasize environmental amenities would be relatively minor to modestly positive (Mathews and others 2002). Other economic effects could include savings to the US Treasury because federal grazing fees on BLM and FS lands cover only about one-sixth of the agencies' administration costs (Vincent 2012). Most significantly, improved ecosystem function would lead to enhanced ecosystem services, with broad economic benefits. Various studies have documented that the economic values of other public-land resources (e.g., water, timber, recreation, and wilderness) are many times larger than that of grazing (Haynes and others 1997; Laitos and Carr 1999; Patterson and Coelho 2009).

Facilitating adaptation to climate change will require changes in the management of public-land ecosystems impacted by ungulates. How ungulate management policy changes should be accomplished is a matter for the agencies, the public, and others. The recommendations and conclusions presented in the following section are based solely on ecological considerations and the federal agencies' legal authority and obligations.

\section{Recommendations}

We propose that large areas of BLM and FS lands should become free of use by livestock and feral ungulates (Table 2) to help initiate and speed the recovery of affected ecosystems as well as provide benchmarks or controls for assessing the effects of "grazing versus no-grazing" at significant spatial scales under a changing climate. Further, large areas of livestock exclusion allow for understanding potential recovery foregone in areas where livestock grazing is continued (Bock and others 1993).

While lowering grazing pressure rather than discontinuing use might be effective in some circumstances, public land managers need to rigorously assess whether such use is compatible with the maintenance or recovery of ecosystem attributes such as soils, watershed hydrology, and native plant and animal communities. In such cases, the contemporary status of at least some of the key attributes and their rates of change should be carefully
Table 2 Priority areas for permanently removing livestock and feral ungulates from Bureau of Land Management and US Forest Service lands to reduce or eliminate their detrimental ecological effects

Watersheds and other large areas that contain a variety of ecotypes to ensure that major ecological and societal benefits of more resilient and healthy ecosystems on public lands will occur in the face of climate change

Areas where ungulate effects extend beyond the immediate site (e.g., wetlands and riparian areas impact many wildlife species and ecosystem services with cascading implications beyond the area grazed)

Localized areas that are easily damaged by ungulates, either inherently (e.g., biological crusts or erodible soils) or as the result of a temporary condition (e.g., recent fire or flood disturbances, or degraded from previous management and thus fragile during a recovery period).

Rare ecosystem types (e.g., perched wetlands) or locations with imperiled species (e.g., aspen stands and understory plant communities, endemic species with limited range), including fish and wildlife species adversely affected by grazing and at-risk and/or listed under the ESA

Non-use areas (i.e., ungrazed by livestock) or exclosures embedded within larger areas where livestock grazing continues. Such non-use areas should be located in representative ecotypes so that actual rates of recovery (in the absence of grazing impacts) can be assessed relative to resource trend and condition data in adjacent areas that continue to be grazed

Areas where the combined effects of livestock, wild ungulates, and feral ungulates are causing significant ecological impacts

monitored to ascertain whether continued use is consistent with ecological recovery, particularly as the climate shifts (e.g., Karr and Rossano 2001, Karr 2004; LaPaix and others 2009). To the extent possible, assessments of recovering areas should be compared to similar measurements in reference areas (i.e., areas exhibiting high ecological integrity) or areas where ungulate impacts had earlier been removed or minimized (Angermeier and Karr 1994; Dobkin and others 1998). Such comparisons are crucial if scientists and managers are to confirm whether managed systems are attaining restoration goals and to determine needs for intervention, such as reintroducing previously extirpated species. Unfortunately, testing for impacts of livestock use at landscape scales is hampered by the lack of large, ungrazed areas in the western US (e.g., Floyd and others 2003; FWS 2010).

Shifting the burden of proof for continuing, rather than significantly reducing or eliminating ungulate grazing is warranted due to the extensive body of evidence on ecosystem impacts caused by ungulates (i.e., consumers) and the added ecosystem stress caused by climate change. As Estes and others (2011, p. 306) recommended: "[T]he burden of proof [should] be shifted to show, for any ecosystem, that consumers do (or did) not exert strong cascading effects" (see also Henjum and others 1994; Kondolf 1994; Rhodes and others 1994). Current livestock or feral 
ungulate use should continue only where stocking rates, frequency, and timing can be demonstrated, in comparison with landscape-scale reference areas, exclosures, or other appropriate non-use areas, to be compatible with maintaining or recovering key ecological functions and native species complexes. Furthermore, such use should be allowed only when monitoring is adequate to determine the effects of continued grazing in comparison to areas without grazing.

Where wild native ungulates, such as elk or deer, have degraded plant communities through excessive herbivory (e.g., long-term suppression of woody browse species [Weisberg and Coughenour 2003; Beschta and Ripple 2009; Ripple and others 2010]), state wildlife agencies and federal land managers need to cooperate in controlling or reducing those impacts. A potentially important tool for restoring ecosystems degraded by excessive ungulate herbivory is reintroduction or recolonization of apex predators. In areas of public land that are sufficiently large and contain suitable habitat, allowing apex predators to become established at ecologically effective densities (Soulé and others 2003, 2005) could help regulate the behavior and density of wild ungulate populations, aiding the recovery of degraded ecosystems (Miller and others 2001; Ripple and others 2010; Estes and others 2011). Ending government predator control programs and reintroducing predators will have fewer conflicts with livestock grazing where the latter has been discontinued in large, contiguous public-land areas. However, the extent to which large predators might also help control populations of feral horses and burros is not known.

Additionally, we recommend removing livestock and feral ungulates from national parks, monuments, wilderness areas, and wildlife refuges wherever possible and managing wild ungulates to minimize their potential to adversely affect soil, water, vegetation, and wildlife populations or impair ecological processes. Where key large predators are absent or unable to attain ecologically functional densities, federal agencies should coordinate with state wildlife agencies in managing wild ungulate populations to prevent excessive effects of these large herbivores on native plant and animal communities.

\section{Conclusions}

Average global temperatures are increasing and precipitation regimes changing at greater rates than at any time in recent centuries. Contemporary trends are expected to continue and intensify for decades, even if comprehensive mitigations regarding climate change are implemented immediately. The inevitability of these trends requires adaptation to climate change as a central planning goal on federal lands.
Historical and on-going ungulate use has affected soils, vegetation, wildlife, and water resources on vast expanses of public forests, shrublands, and grasslands across the American West in ways that are likely to accentuate any climate impacts on these resources. Although the effects of ungulate use vary across landscapes, this variability is more a matter of degree than type.

If effective adaptations to the adverse effects of climate change are to be accomplished on western public lands, large-scale reductions or cessation of ecosystem stressors associated with ungulate use are crucial. Federal and state land management agencies should seek and make wide use of opportunities to reduce significant ungulate impacts in order to facilitate ecosystem recovery and improve resiliency. Such actions represent the most effective and extensive means for helping maintain or improve the ecological integrity of western landscapes and for the continued provision of valuable ecosystem services during a changing climate.

Acknowledgments We greatly appreciate reviews by D.S. Dobkin, S.C. Fouty, J.B. Kauffman, and W.S. Platts of an early draft. We also appreciate the comments, questions, and suggestions provided by two anonymous reviewers. This work was supported by grants to the Geos Institute from the Wilburforce and Wyss foundations and by a Kline Law Faculty Research Fund grant.

\section{References}

Abella SR (2008) A systematic review of wild burro grazing effects on Mojave Desert vegetation, USA. Environ Manage 41:809-819

Allen DL (1974) Our wildlife legacy. Funk and Wagnalls, New York Allington GRH, Valone TJ (2010) Reversal of desertification: the role of physical and chemical soil properties. J Arid Environ 74:973-977

Angermeier PL, Karr JR (1994) Biological integrity versus biological diversity as policy directives. Bioscience 44:690-697

Asner GP, Elmore AJ, Olander LP, Martin RE, Harris AT (2004) Grazing systems, ecosystem responses, and global change. Ann Rev Environ Resour 29:261-299

Backlund P, Janetos A, Schimel D, Hatfield J, Ryan M, Archer S, Lettenmaier D (2008) The effects of climate change on agriculture, land resources, water resources, and biodiversity. A report by the US Climate Change Science Program and the Subcommittee on Global Change Research. US Environmental Protection Agency, Washington, DC, http://www.climate science.gov/Library/sap/sap4-3/final-report/default.htm

Balling RC, Klopatek JM, Hildebrandt ML, Moritz CK, Watts J (1998) Impacts of land degradation on historical temperature records from the Sonoran Desert. Clim Change 40:669-681

Barnosky AD, Hadly EA, Bascompte J et al (2012) Approaching a state shift in Earth's biosphere. Nature 486:52-58

Bates BC, Kundzewicz ZW, Wu S, Palutikof JP (eds) (2008) Climate change and water. In: Technical paper of the intergovernmental panel on climate change. IPCC Secretariat, Geneva

Baxter CV, Fausch KD, Saunders WC (2005) Tangled webs: reciprocal flows of invertebrate prey link streams and riparian zones. Freshw Biol 50:201-220 
Beever EA, Tausch RT, Brussard PF (2003) Characterizing grazing disturbance in semiarid ecosystems across broad scales, using diverse indices. Ecol Appl 13:119-136

Belnap J, Lange OL (eds) (2003) Biological soil crusts: structure, function, and management. Springer-Verlag, New York

Belnap J, Phillips SL, Troxler T (2006) Soil lichen and moss cover and species richness can be highly dynamic: the effects of invasion by the annual exotic grass Bromus tectorum, precipitation, and temperature on biological soil crusts in SE Utah. Appl Soil Ecol 32:63-76

Belsky AJ, Blumenthal DM (1997) Effects of livestock grazing on stand dynamics and soils in upland forests of the interior west. Conserv Biol 11:315-327

Belsky AJ, Matzke A, Uselman S (1999) Survey of livestock influences on stream and riparian ecosystems in the western United States. J Soil Water Conserv 54:419-431

Berger J, Stacey PB, Bellis L, Johnson MP (2001) A mammalian predator-prey imbalance: grizzly bear and wolf extinction affect avian neotropical migrants. Ecol Appl 11:967-980

Beschta RL (1997) Riparian shade and stream temperature: an alternative perspective. Rangelands 19:25-28

Beschta RL, Ripple WJ (2009) Large predators and trophic cascades in terrestrial ecosystems of the western United States. Biol Conserv 142:2401-2414

Beschta RL, Ripple WJ (2012) The role of large predators in maintaining riparian plant communities and river morphology. Geomorphology 157-158:88-98

Beschta RL, Rhodes JJ, Kauffman JB, Gresswell RE, Minshall GW, Frissell CA, Perry DA, Hauer R, Karr JR (2004) Postfire management on forested public lands of the western United States. Conserv Biol 18:957-967

Bestelmeyer BT, Herrick JE, Brown JR, Trujillo DA, Havstad KM (2004) Land management in the American Southwest: a stateand-transition approach to ecosystem complexity. Environ Manage 34:38-51

Binkley D, Moore MM, Romme WH, Brown PM (2006) Was Aldo Leopold right about the Kaibab deer herd? Ecosystems 9: 227-241

Blackburn WH (1984) Impacts of grazing intensity and specialized grazing systems on watershed characteristics and responses. In: Developing strategies for rangeland management. National Research Council, Westview Press, Boulder, pp 927-983

BLM (Bureau of Land Management) (2005) Draft vegetation treatments using herbicides on Bureau of Land management lands in 17 western states. Programmatic EIS. US Bureau of Land Management, Washington, DC

BLM (Bureau of Land Management) (2009) Public land statistics. US Bureau of Land Management, Washington, DC http://www.blm. gov/public_land_statistics/index.htm

BLM and FS (Bureau of Land Management and US Forest Service (1994) Rangeland reform'94: draft environmental impact statement. Washington, DC

Bock CE, Bock JH, Smith HM (1993) Proposal for a system of federal livestock exclosures on public rangelands in the western United States. Conserv Biol 7:731-733

Bowker MA, Miller ME, Belote RT (2012) Assessment of rangeland ecosystem conditions, Salt Creek Watershed and Dugout Ranch, southeastern Utah. US Geological Survey, Scientific Investigations Report 2012-1061, http://pubs.usgs.gov/of/2012/ 1061/

Branson FA, Gifford GF, Renard KG, Hadley RF (1981) Rangeland hydrology. Kendall/Hunt Publishing, Dubuque

Brennan LA, Kuflesky WP Jr (2005) North American grassland birds: an unfolding conservation crisis? J Wildl Manag 69:1-13

Brooks ML (2008) Plant invasions and fire regimes. In: Brown JK, Smith JK (eds) Wildland fire in ecosystems: effects of fire on flora. US Forest Service RMRS-GTR-42, Fort Collins, Colorado, pp 33-45

Brown JH, Valone TJ, Curtin CG (1997) Reorganization of an arid ecosystem in response to recent climate change. Proc Natl Acad Sci 94:9729-9733

CEQ (Council on Environmental Quality) (2010) Progress report of the Interagency Climate Change Adaptation Task Force: recommended actions in support of a National Climate Change Adaptation Strategy. Washington, DC, USA. [online] www. whitehouse.gov/ceq/initiatives/adaptation

Chadde S, Kay CE (1996) Tall-willow communities on Yellowstone's northern range: a test of the "natural regulation" paradigm. In: Singer FJ (ed) Effects of grazing by wild ungulates in Yellowstone National Park. Technical Report NPS/NRYELL/ NRTR/96-01. National Park Service, Denver, pp 165-184

Christensen NL, Bartuska AM, Brown JH, Carpenter S, D'Antonio C, Francis R, Franklin JF, MacMahon JA, Noss RF, Parsons DJ, Peterson CH, Turner MG, Woodmansee RG (1996) The report of the Ecological Society of America committee on the basis for ecosystem management. Ecol Appl 6:665-691

Coggins GC, Wilkinson CF, Leshy JD, Fischman RL (2007) Federal public land and resources law. Foundation Press, New York

Connelly JW, Knick ST, Schroeder MA, Stiver SJ (2004) Conservation assessment of greater sage-grouse and sagebrush habitats. Western Association of Fish and Wildlife Agencies, Cheyenne

Cowley ER (2002) Monitoring current year streambank alteration. US Bureau of Land Management, Boise

CWWR (Centers for Water and Wildland Resources) (1996) Sierra Nevada ecosystem project report. Wildland Resources Center Report No. 39. University of California, Davis

D'Antonio CM, Vitousek PM (1992) Biological invasions by exotic grasses, the grass/fire cycle, and global change. Annu Rev Ecol Syst 23:63-87

Dobkin DS, Rich AC, Pyle WH (1998) Habitat and avifaunal recovery from livestock grazing in a riparian meadow system of the northwestern Great Basin. Conserv Biol 12:209-221

DOI-OIG (Department of the Interior-Office of the Inspector General) (2010) Bureau of land management wild horse and burrow program. Report C-IS-BLM-0018-2010, Washington, DC

Donahue DL (2007) Federal rangeland policy: perverting law and jeopardizing ecosystem services. J Land Use Environ Law 22:299-354

Dwire KA, Ryan SE, Shirley LJ, Lytjen D, Otting N, Dixon MK (2007) Influence of herbivory on regrowth of riparian shrubs following a wildland fire. J Am Water Resour Assoc 42:201-212

EPA (Environmental Protection Agency) (1999) A review and synthesis of effects of alterations to the water temperature regime on freshwater life stages of salmonids, with special reference to chinook salmon, USEPA Technical Report EPA 910-R-99-010. USEPA, Seattle, http://www.maweb.org/documents/document. 355.aspx.pdf

EPA (Environmental Protection Agency) (2009) National water quality inventory: report to congress, 2004 reporting cycle. US Environmental Protection Agency EPA-841-R-08-001, Washington, DC

Estes JA, Terborgh J, Brashares JS, and 21 others (2011) Trophic downgrading of planet earth. Science 333:301-306

Field CB, Mortsch LD, Brklacich M, Forbes DL, Kovacs P, Patz JA, Running SW, Scott MJ (2007) North America. Climate change 2007: impacts, adaptation and vulnerability. In: Parry ML, Canziani OF, Palutikof JP, van der Linden PJ, Hanson CE (eds) Contribution of working group II to the fourth assessment report of the intergovernmental panel on climate change. Cambridge University Press, Cambridge, pp 617-652

Fleischner TL (1994) Ecological costs of livestock grazing in western North America. Conserv Biol 8:629-644 
Fleischner TL (2010) Livestock grazing and wildlife conservation in the American West: historical, policy and conservation biology perspectives. In: du Toit JT, Kock R, Deutsch JC (eds) Wild rangelands: conserving wildlife while maintaining livestock in semi-arid ecosystems. Blackwell Publishing, Boston, pp 235-265

Floyd ML, Fleischner TL, Hanna D, Whitefield P (2003) Effects of historic livestock grazing on vegetation at Chaco Culture National Historical Park, New Mexico. Conserv Biol 17:17031711

Flynn AJ, Alvarez P, Brown JR, George MR, Kustin C, Laca EA, Oldfield JT, Schohr T, Neely CL, Wong CP (2009) Soil carbon sequestration in U.S. rangelands: Issues paper for protocol development. Environmental Defense Fund, Sacramento, http:// cleartheair.edf.org/documents/10673_Soil_Carbon_Sequestration_ white_paper.pdf

FS (Forest Service) (2007) USDA Forest service strategic plan FY 2007-2012. FS-880. www.fs.fed.us/publications/strategic/fs-spfy07-12.pdf

FS and BLM (Forest Service and Bureau of Land Management) (1997) The assessment of ecosystem components in the Interior Columbia Basin and portions of the Klamath and Great Basins, vol I-IV. PNW-GTR-405. US Forest Service and US Bureau of Land Management, Portland

Furniss MJ, Millar CI, Peterson DL, Joyce LA, Neilson RP, Halofsky JE, Kerns BK (eds) (2009) Adapting to climate change: a short course for land managers. US Forest Service PNW-GTR-789, Portland

FWS (US Fish and Wildlife Service) (2010) Endangered and threatened wildlife and plants; 12-month findings for petitions to list the greater sage-grouse (Centrocercus urophasianus) as threatened or endangered. Federal Register 75:13910-14010, Washington, DC

GAO (Government Accountability Office) (2005) Livestock grazing: federal expenditures and receipts vary, depending on the agency and the purpose of the fee charged. US Government Accountability Office GAO-05-869, Washington, DC

GAO (Government Accountability Office) (2007) Climate change: agencies should develop guidance for addressing the effects on federal land and water resources. US Government Accountability Office GAO-07-863, Washington, DC

Genter BJ, Tanaka JA (2002) Classifying federal public land grazing permittees. J Range Manag 55:2-11

Gill RA (2007) Influence of 90 years of protection from grazing on plant and soil processes in the subalpine meadows of the Wasatch Plateau, USA. Rangel Ecol Manag 60:88-98

Gorte RW, Vincent CH, Alexander K, Humphries M (2010) Federal lands managed by the Bureau of Land Management (BLM) and US Forest Service (FS): issues for the 111th congress. Congressional Research Service R40237, Washington, DC

Graves HS, Nelson EW (1919) Our national elk herds. US Department of Agriculture, Departmental Circular 51, Washington, DC

Grover HB, Musick HB (1990) Shrubland encroachment in southern New Mexico, USA: an analysis of desertification processes in the American southwest. Clim Change 16:165-190

GS and AFS (Geological Survey and American Fisheries Society) (2011) Imperiled fish, by ecoregion. http://fl.biology.usgs.gov/ afs_fish/map_object.html

Hanley TA, Brady WW (1977) Feral burro impact on a Sonoran desert range. J Range Manag 30:374-377

Harrington JL, Conover MR (2006) Characteristics of ungulate behavior and mortality associated with wire fences. Wildl Soc Bull 34:1295-1305

Haynes, RW, Horne AL, Reyna NE (1997) Economic evaluation of the preliminary draft EIS alternatives. In: Quigley TM, Lee KM, Arbelbide SJ (eds) Evaluation of the environmental impact statement alternatives by the science integration team. US Forest Service PNW-GTR-406, Portland, Oregon, pp 731-758

Heller NE, Zavaleta ES (2009) Biodiversity management in the face of climate change: a review of 22 years of research. Biol Conserv 142:14-32

Henjum MG, Karr JR, Chu EW (1994) Interim protection for latesuccessional forests, fisheries, and watersheds: national forests east of the Cascade Crest, Oregon and Washington. Wildlife Society Technical Review, Wildlife Society, Bethesda, Maryland

Hunter M Jr, Dinerstein E, Hoekstra J, Lindenmayer D (2010) A call to action for conserving biological diversity in the face of climate change. Conserv Biol 24:1169-1171

IPCC (Intergovernmental Panel on Climate Change) (2007a) Climate change 2007: the physical science basis. In: Solomon S, Qin D, Manning M, Chen Z, Marquis M, Avery KB, Tignor M, Miller HL (eds) Contribution of working group I to the fourth assessment report of the Intergovernmental Panel on Climate Change. Cambridge University Press, UK

IPCC (Intergovernmental Panel on Climate Change) (2007b) Climate change 2007: synthesis report. In: Pachauri RK, Reisinger A (eds) Contribution of Working Groups I, II and III to the Fourth Assessment Report of the Intergovernmental Panel on Climate Change. Geneva, Switzerland

Isaak DJ, Wollrab S, Horan D, Chandler G (2012) Climate change effects on stream and river temperatures across the northwest U.S. from 1980-2009 and implications for salmonid fishes. Clim Change 113:499-524

ITF (Interagency Climate Change Adaptation Task Force) (2011) Draft national action plan: priorities for managing freshwater resources in a changing climate. National Oceanic and Atmospheric Administration, Washington, DC

Jelks HL, Walsh SJ, Burkhead NM, Contreras-Balderas S, Diaz-Pardo E, Hendrickson DA, Lyons J, Mandrak NE, McCormick F, Nelson JS, Platania SP, Porter BA, Renaud CB, Schmitter-Soto JJ, Taylor EB, Warren ML Jr (2008) Conservation status of imperiled North American freshwater and diadromous fishes. Fisheries 33:372-407

Jones MB, Donnelly A (2004) Carbon sequestration in temperate grassland ecosystems and the influence of management, climate and elevated $\mathrm{CO}_{2}$. New Phytol 164:423-439

Joyce LA, Blate GM, Littell JS, McNulty SG, Millar CI, Moser SC, Neilson RP, O'Halloran K, Peterson DL (2008) Adaptation options for climate-sensitive ecosystems and resources: national forests. Environmental Protection Agency, Climate Change Science Program SAP 4.4, Washington, DC

Joyce LA, Blate GM, McNulty SG, Millar CI, Moser S, Neilson RP, Peterson DL (2009) Managing for multiple resources under climate change: national forests. Environ Manage 44:1022-1032

Julius SH, West JM, Barron JS, Joyce LA, Griffith B, Kareiva P, Keller BD, Palmer M, Peterson C, Scott JM (2008) Executive summary. In: Preliminary review of adaptation options for climate-sensitive ecosystems and resources. US Climate Change Science Program and the Committee on Global Change Research, Final Report, Synthesis and Assessment Product 4.4, USEPA, Washington, DC, pp 1-6

Karl TR, Melillo JM, Peterson TC (eds) (2009) Global climate change impacts in the United States. US Global Change Research Program. Cambridge University Press, New York. http://www. globalchange.gov/publications/reports/scientific-assessments/usimpacts

Karnopp J (2008) Elk hunt forecast. Bugle. J Rocky Mount Elk Found 25:84-105

Karnosky DF, Zak DR, Pregitzer KS, and 28 others (2003) Tropospheric $\mathrm{O}_{3}$ moderates responses of temperate hardwood forests to elevated $\mathrm{CO}_{2}$ : a synthesis of molecular to ecosystem results from the aspen FACE project. Funct Ecol 17:289-304 
Karr JR (2004) Beyond definitions: maintaining biological integrity, diversity, and environmental health in national wildlife refuges. Nat Resour J 44:1067-1092

Karr JR (2006) Seven foundations of biological monitoring and assessment. Biol Ambient 20:7-18

Karr JR, Rossano EM (2001) Applying public health lessons to protect river health. Ecol Civil Eng 4:3-18

Kauffman JB, Pyke DA (2001) Range ecology, global livestock influences. In: Levin S (ed) Encyclopedia of biodiversity, vol 5. Academic Press, New York, pp 33-52

Kauffman JB, Beschta RL, Otting N, Lytjen D (1997) An ecological perspective of riparian and stream restoration in the western United States. Fisheries 22:12-24

Kauffman JB, Mahrt M, Mahrt L, Edge WD (2001) Wildlife of riparian habitats. In: Johnson DH, O'Neil TA (eds) Wildlifehabitat relationships in Oregon and Washington. Oregon State University Press, Corvallis, pp 361-388

Kauffman JB, Thorpe AS, Brookshire J, Ellingson L (2004) Livestock exclusion and belowground ecosystem responses in riparian meadows of eastern Oregon. Ecol Appl 14:1671-1679

Kaushal SS, Likens GE, Jaworksi NA, Pace ML, Sides AM, Seekell D, Belt KT, Secor DH, Wingate RL (2010) Rising stream and river temperatures in the United States. Front Ecol Environ 8:461-466

Kleppe v. New Mexico (1976) 426 U.S. 529. U.S. Supreme Court

Knick ST, Hanser SE (2011) Connecting pattern and process in greater sage grouse populations and sagebrush landscapes. In: Knick ST, Connelly JW (eds) Greater sage-grouse: ecology and conservation of a landscape species and its habitats. Studies in avian biology, vol 38. University of California Press, Berkeley

Kondolf GM (1994) Livestock grazing and habitat for a threatened species: land-use decisions under scientific uncertainty in the White Mountains, California, USA. Environ Manage 18:501509

Kondolf GM, Kattelmann R, Embury M, Erman DC (1996) Status of riparian habitat. Sierra Nevada ecosystem project: final report to congress, vol II, chap 36. Wildland Resources Center Report No. 39, University of California, Davis

Laitos JG, Carr TA (1999) The transformation on public lands. Ecol Law Q 26:140-242

Lal R (2001a) The physical quality of soil on grazing lands and its effects on sequestering carbon. In: Follett RF, Kimble JM, Lal R (eds) Potential of U.S. grazing lands to sequester carbon and mitigate the greenhouse effect. CRC Press, Boca Raton, pp 249-266

Lal R (2001b) Soil erosion and carbon dynamics on grazing land. In: Follett RF, Kimble JM, Lal R (eds) Potential of U.S. grazing lands to sequester carbon and mitigate the greenhouse effect. CRC Press, Boca Raton, pp 231-247

LaPaix R, Freedman B, Patriquin D (2009) Ground vegetation as an indicator of ecological integrity. Environ Rev 17:249-265

Love LD (1959) Rangeland watershed management. In: Proceedings, society of American foresters, pp 198-200

Luce CH, Holden ZA (2009) Declining annual streamflow distributions in the Pacific Northwest United States, 1948-2006. Geophys Res Lett 36. doi:10.1029/2009GL039407

Mackie RJ, Pac DF, Hamlin KL, Dusek GL (1998) Ecology and management of mule deer and white-tailed deer in Montana. Montana Fish, Wildlife and Parks, Helena

Mathews KH Jr, Ingram K, Lewandrowski J, Dunmore J (2002) Public lands and western communities. Agricultural Outlook, USDA-Economic Research Service, June-July 2002, pp 18-22

MEA (Millennium Ecosystem Assessment), (2005a) Ecosystems and human well-being: biodiversity synthesis. World Resources Institute, Washington, DC, p 86
MEA (Millennium Ecosystem Assessment) (2005b) Ecosystems and human well-being: desertification synthesis. World Resources Institute, Washington, DC. http://www.maweb.org/documents/ document.355.aspx.pdf

Middleton NJ, Thomas DSG (eds) (1997) World atlas of desertification. U.N. Environment Programme. Edward Arnold, New York

Milchunas DG, Lauenroth WK (1993) Quantitative effects of grazing on vegetation and soils over a global range of environments. Ecol Monogr 63:327-366

Milchunas DG, Lauenroth WK, Burke IC (1998) Livestock grazing: animal and plant biodiversity of shortgrass steppe and the relationship to ecosystem function. Oikos 83:65-74

Miller B, Dugelby B, Foreman D, Martinez del Rio C, Noss R, Phillips M, Reading R, Soulé ME, Terborgh J, Willcox L (2001) The importance of large carnivores to healthy ecosystems. Endang Spec Update 18:202-210

Milly PCD, Kunne KA, Vecchia AV (2005) Global pattern of trends in streamflow and water availability in a changing climate. Nature 438:347-350

Milly PCD, Betancourt J, Falkenmark M, Hirsch RM, Kundzewicz ZW, Lettenmaier DP, Stouffer RJ (2008) Stationarity is dead: whither water management? Science 319:573-574

Mote PW, Hamlet AF, Clark MP, Lettenmaier DP (2005) Declining mountain snowpack in western North America. Bull Am Meteorol Soc 86:39-49

Munson SM, Belnap J, Okin GS (2011) Responses of wind erosion to climate-induced vegetation changes on the Colorado Plateau. Proc Natl Acad Sci 108:3854-3859

Neff JC, Ballantyne AP, Farmer GL, Mahowald NM, Conroy JL, Landry CC, Overpeck JT, Painter TH, Lawrence CR, Reynolds RL (2008) Increasing eolian dust deposition in the western United States linked to human activity. Nature Geoscience 1:189-195

Noss RF, LaRoe III ET, Scott JM (1995) Endangered ecosystems of the United States: a preliminary assessment of loss and degradation. Biological Rep. 28. National Biological Service. Washington, DC

NRC (National Research Council), (2002) Riparian areas: functions and strategies for management. National Academy Press, Washington, DC

Ohmart RD (1996) Historical and present impacts of livestock grazing on fish and wildlife resources in western riparian habitats. In: Krausman PR (ed) Rangeland wildlife. Society for Range Management, Denver, pp 245-279

Ohmart RD, Anderson BW (1986) Riparian habitat. In: Cooperrider AY, Boyd J, Stuart HR (eds) Inventory and monitoring wildlife habitat. US Bureau of Land Management Service Center, Denver, Colorado, pp 169-199

Patterson TA, Coelho DL (2009) Ecosystem services: foundations, opportunities, and challenges for the forest products sector. For Ecol Manage 257:1637-1646

Pederson GT, Gray ST, Woodhouse CA, Betancourt JL, Fagre DB, Littell JS, Watson E, Luckman BH, Graumlich LJ (2011) The unusual nature of recent snowpack declines in the North American cordillera. Science 333:332-335

Peters DPC, Yao J, Sala OE, Anderson JP (2011) Directional climate change and potential reversal of desertification in arid and semiarid ecosystems. Glob Change Biol 18:151-163

Peterson DL, Millar CI, Joyce LA, Furniss MJ, Halofsky JE, Neilson RP, Morelli TL (2011) Responding to climate change in national forests: A guidebook for developing adaptation options. US Forest Service PNW-GTR-855, Portland

Piechota T, Timilsena J, Tootle G, Hidalgo H (2004) The western drought: how bad is it? Eos 85:301-308 
Platts WS (1991) Livestock grazing. In: Meehan WR (ed) Influences of forest and rangeland management on salmonid fishes and their habitats. American Fisheries Society Special Publication 19, Bethesda, pp 389-423

Ponce VM, Lindquist DS (1990) Management of baseflow augmentation: a review. Water Resour Bull 26:259-268

Power TM (1996) Lost landscapes and failed economies. Island Press, Washington DC

Prato T (2011) Adaptively managing wildlife for climate change: a fuzzy logic approach. Environ Manage 48:142-149

Public Lands Council v. Babbitt (2000) 529 U.S. 728. U.S. Supreme Court

Rhodes JJ, Baker WL (2008) Fire probability, fuel treatment effectiveness and ecological tradeoffs in western U.S. public forests. Open For Sci J 1:1-7

Rhodes JJ, McCullough DA, Espinosa FA (1994) A coarse screening process for evaluation of the effects of land management activities on salmon spawning and rearing habitat in ESA consultations. Columbia River Inter-Tribal Fish Commission, Technical Report 94-4, Portland, Oregon

Rich TD, Wisdom MJ, Saab VA (2005) Conservation of priority birds in sagebrush ecosystems. In: Ralph JC, Rich TD (eds) Bird conservation implementation and integration in the Americas, proceedings of the third international partners in flight conference. US Forest Service PSW-GTR-191, Albany, pp 589-606

Richter BD, Braun DP, Mendelson MA, Master LL (1997) Threats to imperiled freshwater fauna. Conserv Biol 11:1081-1093

Rieman BE, Isaak DJ (2010) Climate change, aquatic ecosystems, and fishes in the Rocky Mountain West: implications and alternatives for management. US Forest Service RMRS-GTR-250, Fort Collins, Colorado

Ripple WJ, Rooney TP, Beschta RL (2010) Large predators, deer, and trophic cascades in boreal and temperate ecosystems. In: Terborgh J, Estes J (eds) Trophic cascades: predators, prey, and the changing dynamics of nature. Island Press, Washington, DC, pp 141-161

Root TL, Price JT, Hall KR, Schneider SH, Rosenzweig C, Pounds JA (2003) Fingerprints of global warming on wild animals and plants. Nature 421:57-60

Saab VA, Bock CE, Rich TD, Dobkin DS (1995) Livestock grazing effects on migratory landbirds in western North America. Martin TE, Finch DM (eds) Ecology and management of neotropical migratory birds: a synthesis and review of critical issues. Oxford University Press, UK, pp 311-353

Salvo M (2009) Western wildlife under hoof: public lands livestock grazing threatens iconic species. Wild Earth Guardians, Chandler

Sankey JB, Germino MJ, Glenn NF (2009) Aeolian sediment transport following wildfire in sagebrush steppe. J Arid Environ 73:912-919

Seavy NE, Gardali T, Golet GH, Griggs FT, Howell CA, Kelsey R, Small SL, Viers JH, Weigand JF (2009) Why climate change makes riparian restoration more important than ever: recommendations for practice and research. Ecol Restor 27:330-338

Sedell JR, Beschta RL (1991) Bringing back the "bio" in bioengineering. Am Fish Soc Symp 10:160-175

Shepperd WD, Binkley D, Bartos DL, Stohlgren TJ, Eskew LJ (compilers) (2001) Sustaining aspen in western landscapes: symposium proceedings. US Forest Service RMRS-P-18, Fort Collins, Colorado

Soulé ME, Estes JA, Berger J, Martinez Del Rio C (2003) Ecological effectiveness: conservation goals for interactive species. Conserv Biol 17:1238-1250

Soulé ME, Estes JA, Miller B, Honnold DL (2005) Strongly interacting species: conservation policy, management, and ethics. Bioscience 55:168-176

Steinfeld H, Gerber P, Wassenaar T, Castel V, Rosales M, de Haan C (2006) Livestock's long shadow: environmental issues and options. Food and Agriculture Organization, United Nations

Swanson ME, Franklin JF, Beschta RL, Crisafulli CM, DellaSala D, Hutto RL, Lindenmayer DB, Swanston F (2011) The forgotten stage of forest succession: early-successional ecosystems on forest sites. Front Ecol Environ 9:117-125

Thomas CD, Cameron A, Green RF, and 16 others (2004) Extinction risk from climate change. Nature 427:145-148

Thornton PK, Herrero M (2010) The inter-linkages between rapid growth in livestock production, climate change, and the impacts on water resources, land use, and deforestation. World Bank, Policy Research Paper 5178, Nairobi, Kenya

Torrell LA, Rimbey NR, Bartlett ET, Van Tassell LW, Tanaka JA (2001) An evaluation of the PRIA grazing fee formula. Current issues in rangeland resource economics: symposium proceedings. Western Regional Coordinating Committee on Rangeland Economics WCC-55. New Mexico State University Research Report Series 737, Las Cruces, New Mexico

Trimble SW, Mendel AC (1995) The cow as a geomorphic agent, a critical review. Geomorphology 13:233-253

Valone TJ, Meyer M, Brown JH, Chew RM (2002) Timescale of perennial grass recovery in desertified arid grasslands following livestock removal. Conserv Biol 16:995-1002

Vincent CH (2012) Grazing fees: overview and issues. Congressional Research Service RS21232, Washington DC

Weisberg PJ, Coughenour MB (2003) Model-based assessment of aspen responses to elk herbivory in Rocky Mountain National Park, USA. Environ Manage 32:152-169

Welch BL (2005) Big sagebrush: a sea fragmented into lakes, ponds, and puddles. US Forest Service GTR-RMRS-GTR-144, Fort Collins, Colorado

Westerling AL, Hidalgo HG, Cayan DR, Swetnam TW (2006) Warming and earlier spring increase western U.S. forest wildfire activity. Science 313:940-943

Wilcove DS, Rothstein D, Dubow J, Phillips A, Losos E (1998) Quantifying threats to imperiled species in the United States. Bioscience 48:607-615

Worster D (1992) Under western skies: nature and history in the American west. Oxford University Press, New York

WSWC (Western States Water Council) (1989) Preliminary summary of findings, In: Nonpoint Source Pollution Control Workshop, Midvale, Utah, pp 25-28

Wu L, He N, Wang Y, Han X (2008) Storage and dynamics of carbon and nitrogen in soil after grazing exclusion in Leymus chinensis grasslands of northern China. J Environ Qual 37:663-668 